\title{
CORRESPONDENCE
}

\section{Original life}

SIR - David Dickson has quoted (Nature 14 January, p.87) from Judge Overton's ruling against the creationists in Arkansas. Among these we find "Although the subject of origins of life is within the province of biology, the scientific community does not consider origins of life a part of evolutionary theory". . “The theory of evolution assumes the existence of life and is directed to an explanation of how life evolved. Evolution does not presuppose the absence of a creator or God. . ." Now, these statements show that much of the creationist attack on the synthetic theory of evolution is irrelevant. It would be a pity if that short-term goal contributed towards a long-term predisposition in the minds of the scientific community to continue excluding the origin of life from evolutionary theory. That would not be in line with the views of some important evolutionists who contributed to both disciplines. Nevertheless, a bias against considering origins exists in the minds of many evolutionary biologists - I discovered for example that my textbook Evolutionary Biology (Holt, Rinehart \& Winston, New York, 1972) was not favoured by some teachers because it has a prominent chapter on the origin of life.

The evolutionary process is represented at the molecular level on the one hand and encompasses cosmogony on the other. At some point a theoretical framework covering the entire range of that process will become necessary. Presumably the evolution of molecular systems leads to the origin of life just as the evolution of living systems leads to the origin of ecological systems. Individuals need not become proficient students of all these subjects, but it is quite another argument for an important legal document to declare that part of this subject matter is not considered proper by important exponents of the study of evolution, when that is only the provincial bias of some. Such statements are potentially stultifying and to be regretted by those who otherwise rejoice in Judge Overton's document. Stanley N. Salthe Brooklyn College, New York, USA

\section{All in the Book}

\section{SIR - That anyone writing from the} evolutionists' standpoint is willing to expose such crass ignorance of the creationists' case as does Jon Marks ${ }^{1}$ is almost beyond belief. It is much to be hoped that the tone, let alone the substance, from any creationist writing about evolution would not expose such hostility.

May I answer only the three biblical points raised? Leviticus 11 v. 19 is not taxonomic but gastronomic; (and very prudent at that) it does not attempt a classification of mammalia. Luke 23 v. 43 has the comma incorrectly placed, a point of punctuation well understood over the past four hundred years. Genesis, in respect of the fourth day, as taken up by Origen and later by Voltaire, is explained by Wiseman ${ }^{2}$. It is, I regret, open to both sides of this argument to accuse the other of fraud and obscurantism, but nothing useful is served thereby.

Westminster, London SW1, UK

$$
\text { Frank W. Cousins }
$$

1. Marks, J. Nature 295, 276 (1982).

2. Wiseman, P.J. Creation Revealed in Six Days. The Evidence of Scripture Confirmed by Archaeology, p.128 (London, 1948).

\section{Workers' union}

SIR - The letter from ten Russian scientists (Nature 24/31 December, p.688) is in part an approach to the WFSW. The federation is indeed concerned with the difficulties that can afflict scientific workers in any country. We have been able, in various circumstances, to resolve or prevent serious problems.

We have been aware for several months that certain requests for exit visas from the Soviet Union have remained unanswered. On 3 November 1981 I wrote to the president of the "Educational and Scientific Workers' Union of the USSR'" in Moscow, in conformance with the policy of the federation first to contact our affiliated organization in the country concerned. I asked to be informed of the nature of the difficulties relating to these scientists. I feel certain that Mme

Yanoushkovskaya is making the necessary investigation and that she will soon be able to furnish an explanation.

The list of signatories in the letter published by Nature is not identical to that in a letter I had earlier received; two names have been dropped and four added. I infer that the situation has evolved since last year.

World Federation of J.M. LEGAY
Scientific Workers, Lyon, France

Reagan's right

SIR - The editorial “Reagan's mistake on Soviet sanctions" (Nature 7 January, p.1) is disturbing. Science is not now (as it may have been in Davy's time) merely a pastime for scientists. It has powerful consequences for humanity in both peaceful and war-like activities. If all humankind were one big happy family, then free interchange of science would be both desirable and inevitable. But humanity is divided into groups whose objective is not to have cheery little wars with "sweetness and light" in view down the road, but to destroy each other. Therefore, free exchange of science cannot be allowed. Nature's reasoning resembles that of "pacifists" in the last two Great Wars who helped the enemy and hindered our own war effort because they hated war. We all hate war, and we're all for scientific freedom and exchange. But that is no reason to give science that we've worked or paid for - our science - to people who will use it directly (in weapons) or indirectly, by improving their efficiency, to destroy other people: Poles, Afghanistanis, or us.

R.G.S. BIDWELL

Dalhousie University,

Halifax, Nova Scotia, Canada

\section{An SOS from a Polish scientist}

\section{from a correspondent in Poland}

SIR - It was not an eruption of anger as in Hungary, nor was it the movement of a rather narrow group of politically mature intelligentsia as in the Czechoslovakian spring. It was a vast popular movement, in which men of the arts, literature and science found their usual role as articulaters of popular demands.

This cleansing process began a few years ago. In 1978 the group Doswiadczenie $i$ Przysclość (DiP, Experience and Future) was formed. This small group of scientists and journalists published a number of important reports, their main message being that the country was on the edge of catastrophe and that the very last opportunity of avoiding it by the introduction of essential social reforms had arrived. The authors expected that if their voice was not heard the economy of the country would collapse, leading to social turmoil and possibly bloodshed.

The wave of strikes before August 1980 proved the accuracy of these predictions, but the decline was halted - or, as we see it now, postponed - by the "social contract" signed in the Gdansk shipyard.

Some of those involved in DiP formed an openly acting Komitet Porozumiewawczy Stowarzyszén Twórczych i Naukowych (Coordination Committee of Cultural and Scientific Associations) headed by the philosopher Klemens Szaniawski. This committee played a leading role in the cultural life of the country, especially in preparing and promoting the new law concerning publications, the law aimed at moderating the omnipotent power of censors.

The most spectacular event organized by the committee was the Congress of Culture chaired by the art historian Jan Bialostocki. The congress was planned for three days starting 11 December 1981. Martial law was introduced at midnight December 12 and the last session could not be held.

Among many important speeches delivered during this meeting the most prophetic was the opening address by the president of the Association of Polish Writers, Jan Józef Szczepánski. He compared the congress to the orchestra on board the Titanic. This prophecy was soon verified - several of the participants of the congress met during the night in the corridors of Warsaw prisons, and many are there still.

At the end of 1980 the process of revival of all scientific establishments began with a few fundamental demands: freedom of scientific inquiry, promotion of scientists according to merit, the right of a university to decide on its curricula and a significant role for scientists in formulating the scientific and educational policies of the country. The autonomy of universities and of the academy, including election of their officers, was seen as a necessary institutional guarantee of the promotion of these demands and the improvement of scientific activities. Autonomy became the keynote of the whole process of change.

Of course none of these demands is very clever. But it is also not very innovative for citizens to demand to be able to influence the fate of their own country, or to require history, records and information to be truthful and not selected according to the needs of authorities. However, these demands coming after many years of the opposite policy sounded heretical. And behind this policy there were people still possessing considerable power and by no means ready to resign from it. Continued on page 540 